\title{
THE CONCEPT OF HUMAN RIGHTS IN PRACTICE: CIVIL SOCIETY
}

\author{
Aldona MUSIAŁ-KIDAWA \\ Politechnika Śląska, Wydział Organizacji i Zarządzania; aldona.musial-kidawa@polsl.pl, \\ ORCID: 0000-0001-9525-6348
}

Purpose: The paper presents a fundamental issue for contemporary democracy concerning two basic concepts shaping civic awareness.

Methodology: The main method is the analysis of the subject literature.

Findings: The paper discusses the fundamental values that directly determine a person's status as an individual and a citizen in the state.

Social implications: Reflections on the content of human rights and civil society are essential for the development of a model of citizen-state relations.

Originality/value: The paper indicates the existence of a moral aspect in the relationship between the citizen and the state and its importance for building individual subjectivity and civic awareness.

Keywords: dignity, freedom, equality, humanity, humanism.

Category of the paper: Conceptual paper, General review.

\section{Introduction}

The concepts of human rights and civil society comprise two complementary elements of the modern world of democratic values. These two concepts are associated with the freedom and autonomy of the individual and are not only a necessary condition for living in a social perspective, but above all they give it a sensible value from an axiological point of view. Through the affirmation of democratic values, human existence acquires the value of individualism, efficiency and responsibility. The implementation of the contents of these concepts guarantees human subjectivity and protects the limits of that subjectivity. These two concepts are also nowadays becoming a criterion for assessing the way in which the state's institutions and power structures function, its credibility, the rule of law or humanitarianism. These two concepts, having as their source the principles of moral laws, fundamentally shape the axiology of the state order. 


\section{Sources of human rights ideas}

The idea of human rights founded on the concept of the innate dignity of all people is an essentially bold conviction that human nature tends to transcend its innate weaknesses and raise the level of moral consciousness to abstract values. Human rights are an intellectual response in the individual dimension - to the humiliation of dangerous passions pushing man towards dehumanization and destruction, as well as a response - in the social dimension - to the temptation rooted in man to build total certainty, a world that is unconditionally predictable and perfect in its form. Human rights are an expression of respect for the subjectivity of the individual, recognition of his or her individual expression, a desire to submit to the dictates of moral authority, the hope of building a coherent moral constitution aimed at continuous improvement of actions and attitudes, and the affirmation of solidarity and friendship exemplifying itself in harmonious development and social order. This perspective reveals a very important feature of human rights concerning human nature, it points to a great effort to curb emotions and passions, to master natural instincts, so that man and the humanity he creates turn out to be not so much a natural object, in the existing nature, but a moral category that understands the clear difference between drives conditioned by nature and ethical duties that constitute an absolute foundation for the continuity of civilization. Hence, human rights are non-human in the sense of species, since they do not refer to man as a representative of the natural world, but to man as a rational being, endowed with free will. Human rights and the essence of humanity resulting from them are of a moral nature. Man and humanity "is not defined by specific determinants distinguishing them from other species, but by participation in the field of rational necessity, epistemologically implemented as a set of synthetic judgments a priori, as well as in the sphere of unconditionally compelling moral imperatives which cannot be empirically established" (Kołakowski, 1984, p. 132). Man is, therefore, a moral category, an abstract concept, a being who wants continuous self-creation, exceeding the framework of his individual, measurable and predictable existence, being in this dimension opens the space of consciousness above the individual, because ethical values are updated, in the field of vision of which another person appears, who becomes a reference for observing norms and rules. And man's life itself is rooted in an intellectual loyalty to reason, which creates a free will that henceforth marks life with a conflict of opposing values that remain in constant tension. In fact, this conflict shapes the humanistic subjectivity of man and determines the conditions for his survival as a creator and participant of social life, and this is decisive for the survival of civilization. In the world of nature, on the other hand, man is a completely reified figure, limited by his structure of existence and remaining as if outside himself, a figure reduced to the function of an accidental, labile existence in which the experience of meaning other than instincts and passions does not exist, or is radically reduced to the material content itself and is based on natural inclinations belonging to natural objects. Human rights are therefore a challenge to build 
a space of consciousness in which a specific sacrum becomes subjectivity understood as the affirmation of moral rules, the acceptance of which marks and determines the history of human destiny, and which is exemplified by such concepts and values as free will, freedom, dignity, or justice and equality, and then, on their foundations, already in a broader perspective, build a sense of bond and community in thinking about themselves and others. Human rights make us aware, from a philosophical perspective, that man confirms his presence in the world by becoming, by taking responsibility for life, by affirming a life that ceases to be a place of exile and alienation. The subject of human rights is the assumption about the emancipation of man from the natural world, rejection of the "material" and an attempt to achieve an authentic way of existence. This assumption is based on the conviction that there are rules that not only do not express instinctive action, but that their causative power and moral value are based on the action of reason, proper power and the constitution of man. It is reason that is the instance that helps man to overcome his subjective nature. It is reason that creates the forms and categories that constitute the conditions for any possible experience of all intelligent beings; these forms and categories therefore relate to reason and not to species. Similarly, the reasonableness of the moral life is exemplified in the free will of freely acting beings, which translates into the consequences that humanity is not a natural find, a natural specimen, but an abstract moral category. The effort in shaping the spiritual and moral achievements of mankind is based on a constant desire to find and reconcile freedom of action and unconditionally obliging norn, to seek mutual and balanced relations between them. The fundamental question concerns precisely the absolutely binding norms, the way in which they are established, their moral constitution and their normative consequences, and the answer to this question will determine the future and the structure of reality, in which man will be understood either as an absolutely independent and unchangeable value or as a purely instrumental value. Which value will be strengthened depends on, it seems simple but still not obvious, the distinction between what is good and evil, and that this distinction cannot always depend on our arbitrary decisions, and therefore cannot grow from utilitarian criteria. Human rights are part of this field of metaphysical deliberations that try to consolidate and legitimize a human idea, an idea that cannot be derived from a psychological or anthropological source. The area of social and historical security of every culture depends on the search for criteria of duty, which cannot be empirically proved, and the acceptance and affirmation of which absolves the idea of humanity as a moral concept and man as a morally acting subject, hence, as Kołakowski writes, "it is difficult to define what human dignity is, it is not an empirical finding, but without it we are in trouble when we try to answer the question: why slavery is bad" (Kołakowski, 1999, p. 215). In this difficulty, in this foggy, paradoxically, the unconditional form of rules and duties ennobling man morally is confirmed, and without which the assumption of the unchangeable value of the human person loses its humanistic sense, reducing the dimension of human existence to the notion of zoology. It is hard to resist the impression that it is in concepts that the deeper meaning of human existence and human subjectivity is encoded, and through 
concepts we recognize the fundamental assumptions about the moral destiny of the rational human being. Both in the axiological and semantic sense, the concept of human rights presupposes the existence of a transcendent being, an idea, and in it seeks to consolidate the abstract value of humanity. The idea of human rights is precisely such a concept, and it is philosophically and legally well enough to oppose the unbridled motivations and passions of human nature which are conflicting and which in a way agree to violence, the absence of moral brakes, or the failure to identify the difference between good and evil. The idea of human rights is sufficiently well-founded to promote, to a conclusive degree, the universal awareness and belief that there is humanity and a common human destiny, that we all share in this human solidarity, and that this humanity is a moral category and not a species. Finally, it seems that the idea of human rights is such an optimum that man in his biological condition could and still can achieve. This idea shows the direction of the development of the individual and the community in which he or she participates, on the one hand, to curb innate drives and establish a legal instance and, on the other hand, to establish a subjective barrier against the restraint of this subjectivity on the part of state institutions. The core content of the idea of human rights is an assumption about the freedom of will of rational beings. Kantowska's moral theory focuses on man's ability to recognize the difference between good and evil. It is precisely this ability that is rooted in the power of reason, and on this basis it concerns and embraces all people, hence all people endowed by the power of reason with free will, while remaining morally acting subjects, have an unconditional participation in the morally defined concept of humanity. The Enlightenment Age, searching for moral and intellectual inspirations to sanction human subjectivity, found in Kant's formula "a way out of his own culpable immaturity" the source of the European spirit of individualism, respect for otherness, the secular legal order, tolerance, fraternity, the ability to self-criticise, or to give up the sanction of violence. The Enlightenment, in a way, turned man to man, abandoning faith in religious dogmas, has taken up the challenge of making faith in the unchangeable value of the human person a reality, faith in the irreducible and unique core of his personality, this faith constituted modern humanism with its both cultural power and misery. By power, because this humanism built a moral and social order based on the law of independent reason, the principle of personal rights and the conviction that all human beings are equal and equally valuable. These are the values on which the modern democratic state is founded today and which form our European genetic cultural code. Poverty, because this humanism claims, in extreme conditions, the right to consider that no norm is transcendent, that there are no rules of good and evil that man himself could not decree, that man has an unlimited right to deny absolute values, which he can use according to his own needs and beliefs. In this unstable equlibrum, the Western civilization takes place and shapes its destiny in this spirit of uncertainty and endlessness, the ontological status of Europe is coded and, as Kołakowski notes, "ultimately, it can be said that European cultural identity is confirmed by the refusal to accept any endless identification, i. e. in uncertainty and anxiety" (Kołakowski, 1984, p. 15). The essence of the idea of human rights is the recognition of the inherent and 
inalienable rights which a human being acquires at birth and which belong by virtue of being human. It is, and was, a historically revolutionary assumption, since it indicates the autonomy of the individual to whom it attributes absolute value as a moral subject, grants personal rights and rights to participate in power, and also protects against interference by the individual in spheres henceforth considered personal and private. This is not a revolutionary assumption from a transcendental perspective, and it is the source of the criteria of duty, rules and absolutely binding norms that are justified in the supreme instance of reason. Human rights are therefore a morally established reality, the source justifying and proving the existence of these rights can only be a reference to transcendence and not to anthropology. Kołakowski points out that this is a matter of judgment for the life of societies and civilisations: "humanity is a moral concept and if we do not recognise it, we do not have any good grounds to question slavery or the ideology of slavery" (Kołakowski, 1984, p. 139). Thus, Kant's legacy is stamped in the philosophy of human rights as a form of existence of the human person and as a form of this existence it shapes not only a system of valuations which becomes integrative and meaningful, but above all it indicates that the notion of man can only exist as an abstract category, in consequence it means that man in this sense is not a natural object, but exists as a moral object. The possibility of experiencing the world through Kant's moral rules means that there is a perspective of what is human, that every human being as a rational being is secured in the fundamental rights he is entitled to by virtue of his participation in human nature, as a consequence of which every human being should be treated as an end in itself, never as a means. This conviction autonomizes the human individual in his or her rights, concretizing himself or herself in the acceptance of the universal consciousness that man can not only be free, but that no man can belong to another man by becoming his or her property. Thus the concept of humanity as a moral category can effectively oppose the evil of slavery or its version of social Darwinism. The consequence of a moral theory about rational and free moral subjects is the basic premise on which the idea of human rights is based, concerning the inherent and inalienable dignity of the human being as a source of his freedom, equality and rights. This is a fundamental issue for legal and political solutions in a modern democratic state, since, in addition to the positive law established by the institutions of the state, the dignity of the individual as an expression of the natural law must be taken into account and respected by the positive law. Any rule of positive law that violates fundamental moral norms, which clearly violates those norms or is unjust may be considered unlawful and cease to apply. The right to dignity as an innate individual is independent of the positive law that is being established and is a reference for the system of values that positive law seeks to promote and implement. The concept of human dignity is fundamental to human freedoms and rights. It is from the inherent dignity of the human being that his freedom and right. „The recognition of inherent dignity as the source of all rights indicates that they are secondary to the person, indicates their subordination to the good of the person. The raison d'être of existence and such and not other content is man, they do not have an independent existence. The relationship to the good of the 
human being as a whole is an integral part of every law and cannot be disregarded when determining the content of the demands made. Consequently, the ultimate point of reference for a legal order that protects or respects human rights is not those rights, but the human person" (Piechowiak, 1999, p.78).

\section{Civil society: idea and practice}

The modern democratic state shaped as a result of the religious conflicts of the 16th and 17 th centuries is defined by the adoption of the fundamental principle of equality of citizens before civil and political law. The institutionalisation of civil law is carried out through independent courts and is expressed in the principle of habeas corpus. Political rights including, inter alia The right to vote and to stand for election is a right to express one's opinion and a basis for political decisions. The order of a democratic state is above all the protection of the common good understood as the sum of conditions of social life "which allow either associations or individual members of society to achieve their own perfection more fully and easily" (Novak, 1998). The political system of democracy is therefore the consequence of such secular relations of a society liberated from all superstitions and religious dogmas, as well as universal education that strengthens independence of judgement and tolerance. However, active participation in public life is not a value in itself, especially as being a citizen is about ensuring equal treatment and having a real influence on decision making. The system of a democratic state, by defining the scope of citizens' rights and duties, shapes at the same time a mechanism of political responsibility, responsibility that conditions political consensus that enables identification with others and limits the threat of turning social dialogue into a phenomenon of ideological struggle: "the social system of democratic nations does not lead to revolution, but rather distances them from them" (Tocqueville, 1996). Society is looking for the principle of "balanced majority consent" rather than absolute unity, which means negation and elimination of all differences, because man, i. e. a citizen of society, has been secured in the inalienable right to formulate his own views. Tocqueville notes that man as a social being is neither completely free nor totally enslaved, and that this particular extent makes it up to him whether this development process will lead to submission or freedom, to enlightenment or to barbarism (Tocqueville, 1996). As a consequence, the choice of how to understand freedom and equality may manifest itself in the economic sphere as a zone of prosperity or misery. The ability to actively participate in the liberal order of a democratic society is a principle of co-management, i. e. responsibility and moral and political consequences of elections. The position of the citizen is thus shaped not only as a prospect of respect for his or her right to privacy, but also as a commitment to strengthening the democratic power structure. The effectiveness of democratic governance is tested by means of properly formed social ties, 
which are not only a precondition for reconciling selfish reasons, but above all the framework of a pluralistic society. The common good is a rationally justified model of one's own and group's value hierarchies, the ability to cooperate collectively, the ability to debate for political consensus. The consequence of community awareness is the formulation of a concept of actions that determine the condition of the state and society, a concept that goes beyond short-term benefits. Democratic solutions require knowledge of legal and political principles. The basis of their presence remains respect for and adherence to established solutions in the field of law and morality as superior values. The sustainability of democracy (Kołakowski, 1984) is subordinated to responsibility for public affairs, including dependence on the strength of tradition. The definition of democracy determines the position and status of a person, defines the degree of moral commitment expressed by the need for competence and tolerance necessary for the proper assessment of phenomena, for building and supporting the subjectivity of the individual. A sufficiently high level of competence and tolerance also determines the right proportions of individualism, especially since the morality of social life is an implication of morality in the private area. The definition of democracy therefore focuses not only on the institutional forms of a pluralistic system, the proper electoral law, the principle of balance of power, or the shape of the constitution. The political tradition of democracy also indicates the cultural layer, which exists as an experience of proper evaluation of phenomena, to consolidate the principles of representativeness, justice, compromise, respect for minorities and human rights. An active civil society is not only the sum of civic communities and common goals, it is also a community of values, sharing of virtues and customs by the participants of these communities (Putnam, 1995). The ideal of democracy is realized in a society living with the awareness of the idea of the common good, the value shaping the relationship between the mutual dependence of public life and the ability to cooperate. The common good, while remaining a moral value of society, is in opposition to the notion of the universal will of the people in the form of the unlimited right to pursue selfish interests. The common good, not being the same as the will of the people or the will of the general public, is achieved through consensus, i. e. the resignation of each group and individual from part of the particular benefits and goals. Democracy aware of the moral consequences of the choice between the common good and the common will of the people is a limited democracy and realizes the ideal of civil society. The concept of "civil society" points to a society of competent people, capable of formulating critical opinions, realizing the ideal of compromise and moral individuals realizing the value of the common good together with the inalienable right to express their own views. The model of civil society is centred around the idea of the human being as an individual who directs and organizes the world with his free will and has the inalienable right to make personal decisions. As a supreme value, man becomes a civil society actor in confrontation with himself and through his fellow citizens and can freely articulate ethical values and express interests and needs in the economic sphere. Individualism, which is the basic content of civil society, is defined by the right to implement the plans, intentions or ambitions of an individual who has 
a free will source of independence. However, Individulism is not only a relationship of rights, it is also a way to understand the condition of a person entangled in reality. Individualism is therefore also a way out of the trap of any social utopia that guarantees the perfect overcoming of the tragedy of the structure of human existence. For, as Kołakowski points out, the world of human goals and desires is real and inevitable, and man as a creative individual, free through individualism, reduces this conflict not in a perfect way, but allowing the rationality of the world to be preserved in a safe way (Kołakowski, 1999). In the life of every culture it is a condition of its existence. In social practice this means that a social hierarchy is formulated, because "in an open society many people seek social advancement and take the place of other people" (Popper, 1993, p. 45). The development of the social hierarchy is not only achieved through structured operating procedures, but is an expression of a functioning system of values such as justice, equality, competition and humanity. The principle of civil society organisation also requires a serious reduction in the role of the state and the centralised authority that represents it in favour of an institutionalised society. Civil society requires that the authorities respect citizens' rights and are guided primarily by their welfare. This issue continues to dominate society's relations with the state, especially as the democratic state and civil society require constant and partnership-based cooperation in the area of society, citizen, the state through the participation of political and social institutions, so that subsequent changes of power are carried out without shocks, while respecting the value of the autonomous structure of civil society. Dahrendorf points out that democracy and civil society determine the political quality of social relations by creating the rule of law and making freedom a reality (Dahrendorf, 1993). The limited power of the state is sufficient to guarantee the independent position of civil society, a strengthened position, inter alia a change in the meaning of the concept of privilege. Civil society controls and criticises the ruling power using democratic institutions that support freedom and the system of rights. The credibility of democracy is tested by its experience in the daily practice of social life, by its compliance with established norms and rules. The priority is the broadly understood principle of citizen's freedom as freedom of speech, freedom of association, freedom of decision, freedom of choice, or freedom of competition. Contemporary American political scientist Huntington notes that the competence of democracy does not come down to simple principles of social engineering and is not an easy mechanism to achieve economic growth and increase the income level of society. Democracy will also not protect against incompetent or cynical governments. Democracy works well when it is first and foremost in the hearts and minds of citizens, because it is intended to protect the fundamental public and political rights that uphold civil liberties (Huntington, 1995).

The philosophy of the Enlightenment, together with the evolution of bourgeois liberalism, pointed to the value of individual rights in relation to the aspirations of the state, which should only be an instrument to safeguard the natural rights of the individual. Based on individualism, the idea of a citizen, a fully-fledged member of the community, secured by the right of freedom, the right of equality, including the right to property, has developed. An established set of natural 
rights guaranteed the individual's independence, providing for its sovereignty over the structures of the state. The Enlightenment era strengthened the sovereignty of the people based on the sovereignty of the individual. The Enlightenment's idea of the laws of nature committed the state to securing human rights as comprehensively as possible, while at the same time setting the limits and scope of power activities towards the individual and society. For Locke, who made the social contract the foundation of civil society, the state is a secondary result of the organisation of that society, a society forming a government, establishing a political community. The social contract is an expression of the society's adaptability, it is a wave that raises awareness and at the same time exceeds dependence on conditions imposed by nature. Thanks to it, the emancipation of man from nature takes place, which means that man can effectively protect rights such as the right to property, the right to freedom. It is also paradoxical that man, thanks to a social contract, protects the values with which nature has equipped him (Sylwestrzak, 1994). This design means, among other things that any change of government has no political consequences in terms of dissolution of society. Such a strong rooting of the idea of citizenship can be a strong safeguard against the mechanism of escape from freedom, against the invalidation of subjectivity, because there is always a temptation to give up the independence of the individual "I" in favour of a reified, tribal bond. Therefore, a change in political structures, labile or defective political life does not directly affect the stability of a society, which is a fundamental link in the organisation of the lives of individuals or groups. Although the existence of the state in Locke's philosophy is based on a wide range of powers entrusted to the government, the permanence and political stability of the government is only guaranteed if the terms of the social contract are respected, and its violation threatens a revolutionary change in power structure. The doctrine of liberalism has equipped the state, in accordance with the content of the social contract, with a wide range of competences enabling the repression of individuals who do not submit to the letter of the law. Such an interpretation of the role of the state draws attention to the purpose and limits of power intervention in the life of civil society. Apparently, this is evident in Hobbes' concept of social contract. His contractual vision of the state clearly shows that society is renouncing violence in favour of the Sovereign. It is therefore the highest dimension of freedom, freedom from violence. At the same time, it should be stressed that the state is becoming a monopoly of violence. This is a sine qua non condition for civil liberties. His violation is a return to a situation where homo homini lupus est. Civil society therefore has the task of protecting the individual from overwhelming power through the institutions of social life, on the one hand, and safeguarding the rights to express the sovereign will of the individual on the other (Kołakowski, 1999). Monteskius' aristocratic liberalism built the foundations of civil society on the basis of monarchic rule, referring to English models. Unlike Locke, who expressed limited confidence in the institutions of the state, it was through the state, of which the monarchy remained the expression, that Monteskius established the basis of the rule of law and freedoms. In particular, the principle of moderation of the constitutional monarchy, i.e. the legal limitations of the authorities secure the balance 
between those in power and members of civil society. The search for consensus creates conditions that reduce the danger of political antagonisms in the form of anarchy and despotism. Monteskius assumed the existence of a strong constitutional monarchy, identifying its strength and powers with respect for the freedom of the citizen and respect for the rights of the people (Aron, 1997). Only the implementation of the principle of moderate rule has been able to guarantee the political freedom of society, which in practice comes down to a conscientious observance of the virtues, because experience shows that a person with power is prone to abuse it and goes on as long as he meets the limits. The security of the freedom of individuals and society is defined by the principle of rights, because "freedom is the right to do everything that laws allow". Thus, Monteskius recognizes civil liberties in the idea of the rule of law, without which freedom does not exist. By implementing the principle of respect for civil liberties and being a guarantor of individual security, the law balances the balance of power between the competences of the state, central authority and civil society. According to Monteskius, the state must not jeopardise civil society. In this sense, a strong state is not synonymous with despotic, totalitarian power. The power of the state is based on its competence, effectiveness, on clearly defined rules of law, in a three-tier division of powers (Siciński, 1993, pap.). Monteskius' thought introduced a new form of organization of the state, basing it on respect for individual freedom as a fundamental value defended by the rule of law. The law has gained full legitimacy by establishing relations between society and the state, expressing itself in practice and rationality, and constituting a force and value superior to the state institutions. Today, the problem of the dominance of the democratic state becomes particularly important: whether and how a democratic state threatens the ideals of civil society, whether such a state can threaten an individual, how it should be protected from the overwhelming institutionalisation of the state. Structured and stable relations between the citizen and the state are concluded between the principle of freedom, which determines the citizen's rights, and the principle of state competence, which are strictly defined and cannot hinder the citizen's freedom and activity. The competence of the state is primarily to define its area of activity in relation to the citizen's freedom, i.e. the possibility for the citizen to do what is not prohibited (Aron, 1997). Contemporary philosophers place the essence of the problem between the content of a ban and a warrant, where freedom is a reality free of warrants, but without the need to eliminate bans: "freedom without limitation becomes conceptually impossible" (Kołakowski, 1999, p.170). Moreover, the concept of a democratic state in this perspective does not mean systematic interference in all areas of life and does not contradict the meaning of a 'strong state', since the strength of the state is constituted by a deeply democratic basis for action: "without the effective performance of the state's tasks, the effective functioning of civil society is not possible" (Siciński, 1993, pap.). A feature of civil society remains its autonomy from state structures. The society hinders and balances the state's interests and actions aimed at despotic forms of governance based on a network of horizontal links between individuals and groups. 


\section{Conclusion}

The idea of human rights and the idea of civil society are two values and two criteria that shape the contemporary image of parliamentary democracy. Their essential role is focused on building and consolidating the awareness of the civic subjectivity of each participant in social life, and they are a source for the established law, whose main objective and task is to protect and respect this very subjectivity of the human being and citizen. Human rights as morally established are a rudimentary element of the transcendent category of humanity. It is from this position that the state law is evaluated and analyzed, which is absolutely obligated to respect moral values of human rights. Any legal provision which fails to comply with these values shall cease to have effect. The strength of civil society is based on this assumption. These otherwise enigmatic, empirically difficult to prove abstract values not only uphold our civil rights, but also seriously neutralize the passions of an unintelligent nature so as to limit the unpredictability of our actions, which may lead to dehumanization and degrade the human being morally.

\section{References}

1. Aron, R. (1997). Esej o wolnościach. Warszawa: Aletheia.

2. Dahrendorf, R. (1993). Nowoczesny konflikt społeczny: esej o polityce wolności. Warszawa: Czytelnik.

3. Huntington, R. (1995). Trzecia fala demokratyzacji. Warszawa: PWN.

4. Kołakowski, L. (1984). Czy diabeł może być zbawiony. Londyn: Aneks.

5. Kołakowski, L. (1999). Moje stuszne poglady na wszystko. Kraków: ZNAK.

6. Novak, M. (1998). Wolne osoby i dobro wspólne. Kraków: ZNAK.

7. Piechowiak, M. (1999). Filozofia praw człowieka. Prawa człowieka w świetle ich międzynarodowej ochrony. Towarzystwo Naukowe Katolickiego Uniwersytetu Lubelskiego.

8. Popper, K. (1993). Społeczeństwo otwarte i jego wrogowie. Kraków: PWN.

9. Putnam, D. (1995). Demokracja w działaniu. Kraków: ZNAK.

10. Siciński, A. (1993, pap.). O idei społeczeństwa obywatelskiego. Wiedza i Życie, $n r$ 6, Kraków, p. 44.

11. Sylwestrzak, A. (1994). Historia doktryn politycznych. Warszawa: PWN.

12. Tocqueville, A. (1996). O demokracji w Ameryce. Kraków: ZNAK. 